\title{
Wpływ dodatku zwiększającego liczbę cetanową na właściwości zapłonowe i proces spalania oleju napędowego w silniku o zapłonie samoczynnym
}

\begin{abstract}
W artykule przedstawiono proces tworzenia mieszanki paliwowo-powietrznej w silniku z zapłonem samoczynnym oraz czynniki mające wpływ na właściwości zapłonowe oleju napędowego, w tym na opóźnienie fizyczne i chemiczne zapłonu. Zaprezentowano również mechanizm przebiegu reakcji chemicznych obniżających opóźnienie zapłonu chemicznego przy użyciu alkiloazotanu jako dodatku cetanowego.
\end{abstract}

Słowa kluczowe: mieszanka paliwowo-powietrzna, opóźnienie fizyczne i chemiczne zapłonu, reakcje przedpłomieniowe, azotan alkilu.

\section{The effect of the cetane number improver on the ignition properties and combustion process of diesel fuel in a compression ignition engine}

\begin{abstract}
This article presents the process of establishing the air/fuel mixture in a compression-ignition engine, and the factors that affect the ignition properties of the diesel fuel, including the physical and chemical delay of the ignition. The mechanism of the chemical reactions that reduce the chemical delay using alkyl nitrate as a cetane improver was also presented.
\end{abstract}

Key words: air-fuel mixture, ignition physical and chemical delay, pre-flame reactions, alkyl nitrate.

\section{Wstęp}

Światowa Karty Paliw (wydanie piąte z roku 2013) zaleca, by olej napędowy kategorii 4 i 5 zawierający FAME i/lub inne biokomponenty typu HVO (Hydrotreated Vegetable Oil) uwodornionych olejów roślinnych lub BTL (Biomass to Liquid) ciekłych paliw z biomasy miał liczbę cetanową minimum 55 jednostek [40]. Znany jest również ze Światowej Karty Paliw (WWFC 2013) korzystny wpływ liczby cetanowej na rozruch silnika w niskiej temperaturze, jak również na emisję hałasu, cząstek stałych (PM), tlenku węgla (CO), tlenków azotu $\left(\mathrm{NO}_{\mathrm{x}}\right)$ i niespalonych węglowodorów (HC) [6, 24, 40, 42].

Również Parlament Europejski upoważnia CEN do zwiększania liczby cetanowej olejów napędowych do 55 plus w roku 2019 lub 2020 [32].

Zwiększenie liczby cetanowej oleju napędowego ma znaczący wpływ na zmniejszenie zużycia paliwa, szczególnie w przypadku silników pracujących ze stosunkowo niewielkim obciążeniem, a więc w samochodach osobowych i lek- kich pojazdach dostawczych [40]. Większa liczba cetanowa oleju napędowego umożliwia kontrolę opóźnienia zapłonu i przebieg stabilnego spalania, szczególnie w nowoczesnych silnikach wyposażonych w wysokociśnieniowe układy wtrysku paliwa, zwane High Pressure Common Rail System (HPCRS), i recyrkulację spalin. Olej napędowy o większej liczbie cetanowej poprawia właściwości rozruchowe silnika w niskiej temperaturze, zmniejszając cykl rozruchowy silnika. Liczba cetanowa jest miara charakteryzująca zdolność oleju napędowego do samozapłonu w silniku o zapłonie samoczynnym i polega na pomiarze czasu opóźnienia samozapłonu, liczonego pomiędzy początkiem wtrysku paliwa a początkiem spalania wybuchowego, który powoduje wyraźny wzrost ciśnienia [14]. Okres opóźnienia samozapłonu może być wyrażony w milisekundach lub poprzez wartość kąta obrotu wału korbowego silnika przed górnym martwym położeniem tłoka [30]. 


\section{Proces tworzenia mieszanki paliwowo-powietrznej i jej samozapłonu w silniku z zapłonem samoczynnym}

Wtrysk paliwa, tworzenie mieszaniny paliwa i powietrza, jej samozapłon oraz spalanie są złożonymi, powtarzającymi się okresowo szybkozmiennymi procesami, zależnymi od wielu parametrów fizykochemicznych paliwa, zachodzącymi w komorze spalania silnika o zapłonie samoczynnym. Struga rozpylonego paliwa odparowywuje i miesza się z powietrzem sprężonym w komorze spalania, tworząc mieszaninę paliwowo-powietrzną [37].
Właściwości zapłonowe oleju napędowego w silniku o zapłonie samoczynnym zależą od wielu istotnych czynników (charakterystyk), z których najważniejsze to [15]:

- mechaniczna charakterystyka silnika, czyli konstrukcja układu dolotowego i komory spalania silnika, stopień sprężania, układ wtryskowy i rodzaj wtryskiwacza, recyrkulacja spalin, charakterystyka doładowania i ruchu powietrza w komorze spalania,

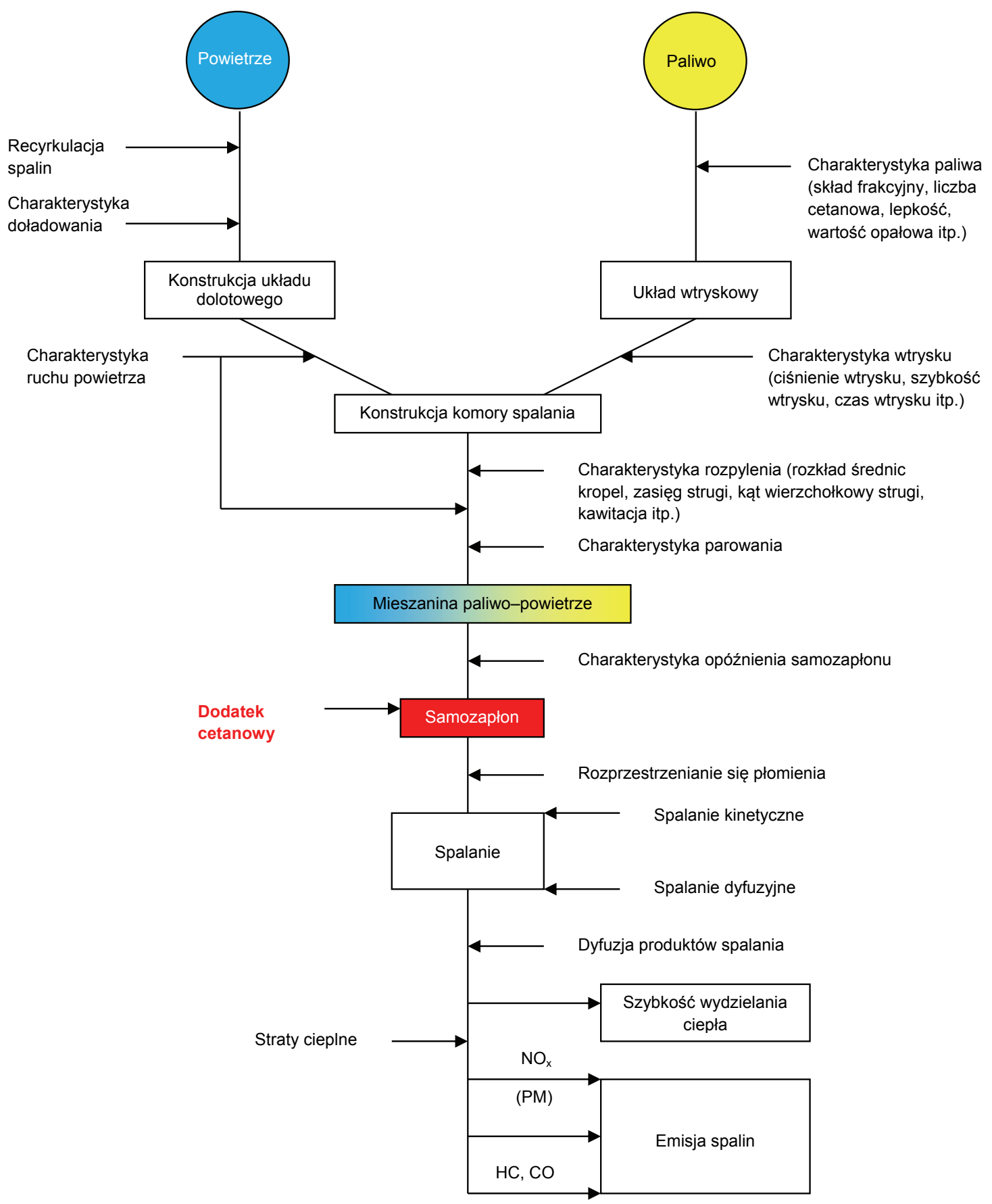

Rys. 1. Schemat tworzenia mieszanki paliwowo-powietrznej, samozapłonu i procesu spalania oleju napędowego [37] 
- charakterystyka paliwa, czyli skład frakcyjny, lepkość, gęstość, napięcie powierzchniowe, lotność, molekularna struktura paliwa,

- charakterystyka wtrysku, w tym jego: ciśnienie, czas trwania, szybkość, czas opóźnienia wtrysku, wielofazowość wtrysku,

- charakterystyka rozpylenia paliwa, w tym zasięg strugi, kąt wierzchołkowy jej, makrostruktura i mikrostruktura strugi, rozkład średnic kropel.

Na rysunku 1 schematycznie przedstawiono proces tworzenia mieszanki paliwowo-powietrznej, samozapłonu i proces spalania oleju napędowego [37].

Istotnym parametrem procesu samozapłonu oleju napędowego jest charakterystyka rozpylenia paliwa $[15,39]$. $\mathrm{Na}$ rysunku 2 przedstawiono makrostrukturę rozpylonej strugi paliwa [27].

Jakość rozpylenia i makrostrukturę rozpylonej strugi paliwa określają następujące trzy parametry fizyczne [19, 27]:

- zasięg czoła strugi rozpylonego paliwa (penetracja strugi),

- kąt wierzchołkowy strugi $(\Theta)$,

- zasięg rozpadu strugi paliwa: pierwotny i wtórny.

Podstawowym parametrem charakteryzującym mikrostrukturę rozpylonego strumienia paliwa jest widmo rozpy- lenia, czyli rozkład kropel według ich średnic i rozkład prędkości kropel w strudze [1, 16, 17].

Dla potrzeb analizy tworzenia strugi paliwa najczęściej stosuje się pomiar średniej objętościowo-powierzchniowej średnicy kropel Sautera (oznaczenie: $d_{32}$ lub $d_{\mathrm{SMD}}$ ), czyli średnicy zastępczej, którą miałyby hipotetyczne krople jednakowego wymiaru, gdyby ich całkowita powierzchnia i całkowita objętość były takie same jak rzeczywistej kropli o kształcie niekulistym $[1,34]$.

Średnia średnica kropel rozpylonego paliwa jest funkcją czterech liczb podobieństwa Webera, Laplace'a lub Ohnesorge'a oraz stosunku gęstości i lepkości dynamicznej paliwa do gęstości i lepkości dynamicznej ośrodka gazowego (ładunku powietrza) [18, 26, 34].

Parametry określające makrostrukturę strugi paliwa (penetracja strugi, kąt wierzchołkowy strugi, zasięg rozpadu pierwotny i wtórny strugi) oraz mikrostrukturę rozpylonej strugi paliwa (rozkład prędkości kropel w strudze i rozkład średnich średnic kropel paliwa) są ze sobą ściśle powiązane i w sposób istotny wpływają na przygotowanie należytego składu mieszanki paliwowo-powietrznej, określonej współczynnikiem nadmiaru powietrza $\lambda$ lub współczynnikiem stechiometrii $\phi[14,38]$.

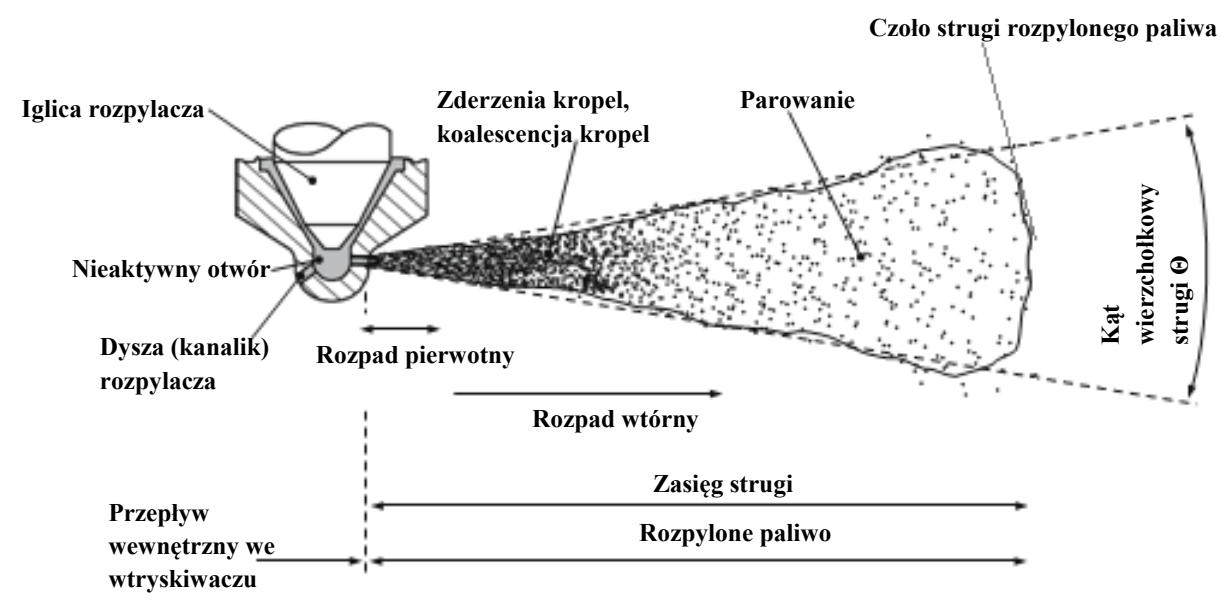

Rys. 2. Makrostruktura rozpylonej strugi paliwa [27]

\section{Właściwości fizykochemiczne i zapłonowe oleju napędowego}

Olej napędowy pochodzący z rafinacji produktów ropy naftowej, określany jako średnie destylaty, to mieszanina ponad stu ciekłych węglowodorów, zawierających od 10 do 20 atomów węgla, o temperaturze wrzenia od $150^{\circ} \mathrm{C}$ do $370^{\circ} \mathrm{C}$.

Średnie destylaty stanowią produkty, które mają wyższy zakres wrzenia niż benzyny i są otrzymywane z destylacji frakcyjnej ropy naftowej lub ze strumieni pochodzących z innych procesów rafineryjnych. Składają się one z normalnych parafin (n-alkanów o prostych łańcuchach), izo- parafin (rozgałęzionych alkanów), olefin (alkenów z wiązaniem podwójnym), monocykloparafin, policykloparafin (dicykloparafin, tricykloparafin) zwanych również naftenami, alkiloaromatów (alkilobenzenów i alkilonaftalenów) oraz wielopierścieniowych węglowodorów aromatycznych [31].

Przykład składu strukturalno-grupowego oleju napędowego o zakresie temperatury wrzenia od $150^{\circ} \mathrm{C}$ do $370^{\circ} \mathrm{C}$ przedstawiono na rysunku 3 . 


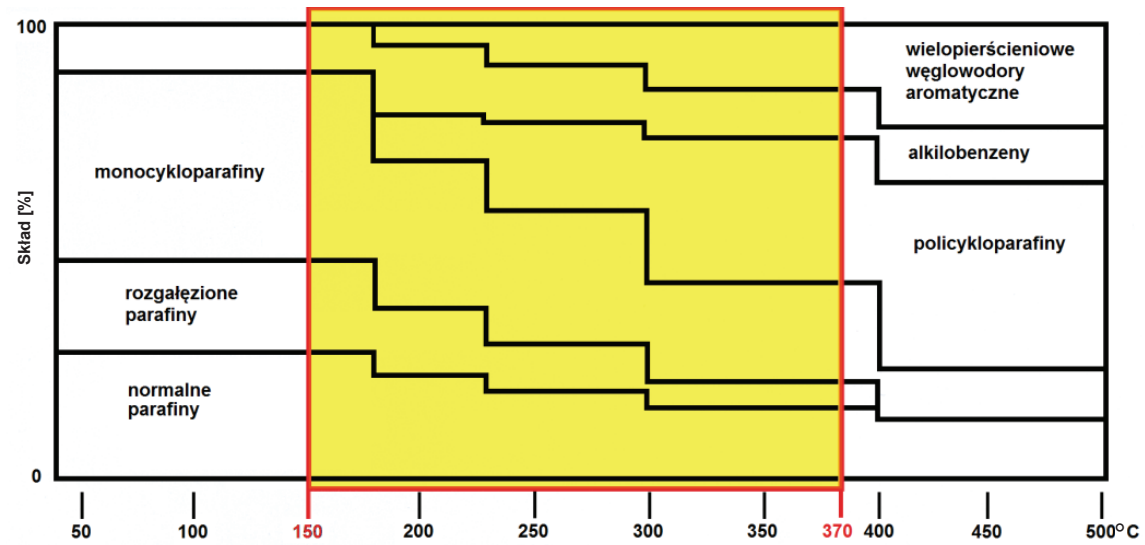

Rys. 3. Skład strukturalno-grupowy oleju napędowego o zakresie temperatury wrzenia od $150^{\circ} \mathrm{C}$ do $370^{\circ} \mathrm{C}$ [31]
Charakterystyczną cechą samozapłonu oleju napędowego jest to, że samozapłon nie następuje natychmiast, lecz po upływie pewnego czasu, który nazywany jest czasem opóźnienia samozapłonu lub zapłonu.

Ze względu na charakter zjawisk fizykochemicznych towarzyszących opóźnieniu samozapłonu rozróżnia się dwie części okresu opóźnienia samozapłonu: fizyczną i chemiczną. Okres opóźnienia samozapłonu zależy od właściwości fizykochemicznych paliwa, takich jak: gęstość, lepkość dynamiczna, napięcie powierzchniowe i międzyfazowe, prężność par, cie-
Typowy olej napędowy zawiera hydroodsiarczony lekki olej napędowy (LON), hydroodsiarczony średni olej napędowy (SON), hydroodsiarczony ciężki olej napędowy (CON), hydroodsiarczoną naftę, frakcję oleju napędowego z krakingu katalitycznego oraz frakcję oleju napędowego z hydrokrakingu. Komponowanie oleju napędowego z poszczególnych strumieni i jego skład strukturalno-grupowy uzależnione są od konfiguracji technologicznej oraz zaawansowania technologicznego rafinerii nafty, wyrażonych wskaźnikiem kompleksowości Nelsona - Nelson's Complexity Index (NCI) [28]. Wskaźnik zaawansowania technologicznego Nelsona przypisuje współczynnik zaawansowania technologicznego dla każdej instalacji procesowej, w oparciu o złożoność procesu technologicznego i koszty, w porównaniu z instalacją destylacji ropy naftowej, której przypisany jest współczynnik zaawansowania technologicznego równy 1,0. Rafinerie o zaawansowaniu technologicznym wyrażonym NCI równym 10 są dziesięciokrotnie bardziej zaawansowane technologicznie niż rafinerie destylujące ropę naftową o tej samej zdolności produkcyjnej [28].

Proces samozapłonu i spalania oleju napędowego w silniku o zapłonie samoczynnym jest sekwencją wielu następczych szybkozmiennych procesów fizycznych i chemicznych, zachodzących w komorze spalania, zależnych od wielu czynników.

Istotnym czynnikiem wpływającym na właściwości zapłonowe oleju napędowego jest skład strukturalno-grupowy paliwa.

Ze względu na dobre właściwości samozapłonowe najbardziej pożądane są oleje napędowe o dużej zawartości n-alkanów (parafin), a najmniej węglowodory aromatyczne. Wadą węglowodorów parafinowych są gorsze niskotemperaturowe właściwości reologiczne.

Mechanizm samozapłonu oleju napędowego polega na wolnorodnikowej reakcji łańcuchowej, rozpoczynającej się od przedpłomieniowego tworzenia „centrów nadtlenkowych”. pło parowania i ciepło spalania, przewodność cieplna, state dyfuzji $[12,35]$.

Na rysunku 4 przestawiono wpływ właściwości fizykochemicznych oleju napędowego na proces tworzenia mieszanki paliwowo-powietrznej i przebieg procesu samozapłonu w silniku o zapłonie samoczynnym $[8,41]$.

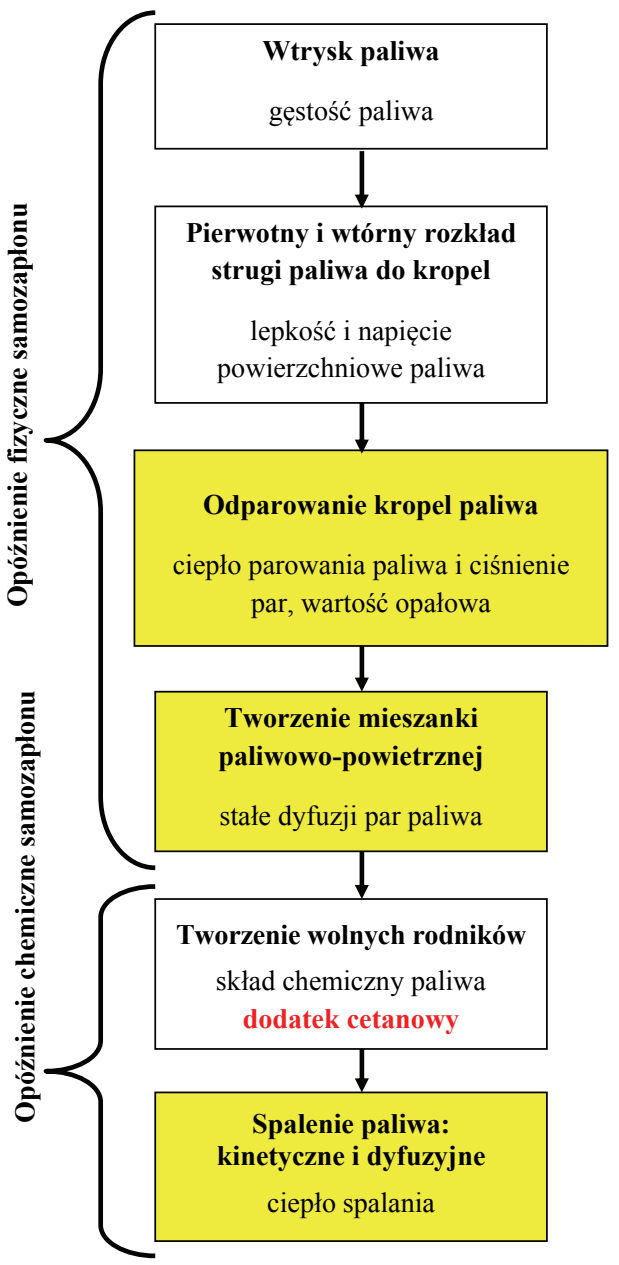

Rys. 4. Wpływ właściwości fizykochemicznych oleju napędowego na proces tworzenia mieszanki paliwowopowietrznej i przebieg procesu samozapłonu w silniku o zapłonie samoczynnym $[8,41]$ 
Część fizyczna opóźnienia samozapłonu obejmuje czas od chwili wtrysku paliwa do momentu, gdy mieszanka paliwowo-powietrzna osiągnie temperaturę inicjacji przedzapłonowych reakcji chemicznych. W tym czasie następuje rozpad pierwotny i wtórny strugi paliwa, częściowe odparowanie i dyfuzja par paliwa z fazy ciekłej. Czas opóźnienia samozapłonu chemicznego jest dużo krótszy od opóźnienia fizycznego samozapłonu i w sposób istotny zależy od temperatury, jak również od parametrów energetycznych oraz chemicznych paliwa. W tym okresie struktura cząsteczkowa paliwa ulega przemianom fizykochemicznym. Na podstawie dotychczasowej wiedzy chemiczne opóźnienie samozapłonu można podzielić na trzy fazy przedstawione na rysunku 5 [43].

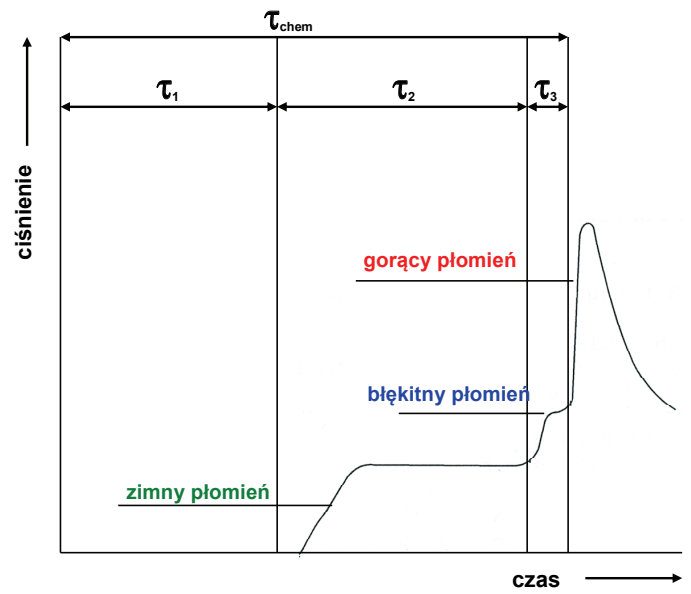

Rys. 5. Przebieg zmiany ciśnienia w funkcji czasu dla opóźnienia chemicznego samozapłonu $\tau_{\text {Chem }}[43]$

Według Zabłockiego [43] część chemiczna opóźnienia samozapłonu obejmuje przebieg wielu chemicznych reakcji łańcuchowych, począwszy od tworzenia wolnych rodników aż do spalania paliwa, a sam czas opóźnienia chemicznego samozapłonu $\tau_{\text {Chem }}$ jest sumą $\tau_{1}, \tau_{2}, \tau_{3}$ i wynosi:

$$
\tau_{\text {Chem }}=\tau_{1}+\tau_{2}+\tau_{3}
$$

gdzie:

$\tau_{1}$ - okres opóźnienia zimnych płomieni,

$\tau_{2}-$ okres opóźnienia niebieskich płomieni,

$\tau_{3}$ - okres opóźnienia gorących płomieni.

Pierwsza faza niskotemperaturowego utleniania oleju napędowego zachodzi w zakresie temperatury od $380^{\circ} \mathrm{C}$ do $480^{\circ} \mathrm{C}$ i obejmuje obszar inicjacji przedzapłonowych reakcji chemicznych oraz pojawienie się zimnych płomieni. W tym zakresie temperatury inicjowane są reakcje rozkładu cząsteczek węglowodorów według reakcji (2) i (3), tworząc dwa rodniki alkilowe lub jeden rodnik alkilowy i rodnik wodoru.

$$
\mathrm{RH}_{\text {(cząsteczka wẹglowodoru) }} \rightarrow \mathrm{R}^{\bullet}+\mathrm{R}^{\bullet}
$$

$$
\mathrm{RH} \rightarrow \mathrm{R}^{\bullet}+\mathrm{H}^{\bullet}
$$

Reakcje (2) i (3) opisują zerwanie wiązań kowalencyjnych z wytworzeniem dwóch rodników i są zależne od struktury cząsteczki. Przeniesienie wodoru między rodnikiem a cząsteczką węglowodoru może być również generowane przez inne reaktywne rodniki według formuły (4)

$$
\mathrm{RH}+\mathrm{X} \rightarrow \mathrm{R}^{\bullet}+\mathrm{XH}
$$

gdzie:

$\mathrm{X}$ - oznacza reaktywny rodnik $\mathrm{H}^{\bullet}, \mathrm{O}^{\bullet},{ }^{\circ} \mathrm{OH}, \mathrm{HO}_{2} \cdot \mathrm{HOO}^{\bullet}$ i $\mathrm{CH}_{3}{ }^{\circ}$, jak również rodnik alkilonadtlenkowy ROO'.

Druga faza rozwoju niskotemperaturowego utleniania oleju napędowego, zachodząca $\mathrm{w}$ zakresie temperatury od $480^{\circ} \mathrm{C}$ do $630^{\circ} \mathrm{C}$, wiąże się z pojawieniem błękitnych płomieni, wzrostem ciśnienia i temperatury oraz reakcją wolnych rodników węglowodorowych $\mathrm{z}$ tlenem według formuł (5-7) [44].

$$
\begin{gathered}
\mathrm{R}^{\bullet}+\mathrm{O}_{2} \rightarrow \mathrm{ROO}_{\text {(rodnik alkilonadtlenkowy) }}^{\bullet} \\
\mathrm{ROO}^{\bullet}+\mathrm{RH} \rightarrow \mathrm{ROOH}_{\text {(wodoronadtlenki) }}+\mathrm{R}^{\bullet} \\
\mathrm{R}^{\bullet}+\mathrm{O}_{2} \rightarrow \mathrm{R}_{\text {(alkeny i dieny) }}^{\prime}+\mathrm{HO}_{2}{ }^{\circ}
\end{gathered}
$$

Alkilorodniki mogą ulegać wewnętrznej izomeryzacji oraz dalszemu rozkładowi podlegając $\beta$-rozkładowi, tworząc cząsteczki z podwójnym wiązaniem.

Rodniki alkilonadtlenków ROO` ulegają wewnętrznej izomeryzacji poprzez transfer wodoru, tworząc rodnik alkilowodoronadtlenku według reakcji (8).

$$
\mathrm{ROO}^{\bullet} \leftarrow \mathrm{QOOH}
$$

Utworzony rodnik alkilowodoronadtlenku ulega reakcji (9) z tlenem, tworząc rodnik alkilonadtlenkowodoronadtlenku lub podlega rozkładowi według reakcji (10) do rodnika hydroksylowego ${ }^{\circ} \mathrm{OH}$ i cyklicznego eteru.

$$
\begin{gathered}
\mathrm{QOOH}^{\bullet}+\mathrm{O}_{2} \rightarrow \mathrm{OOQ}^{\prime} \mathrm{OOH}^{\bullet} \\
\mathrm{QOOH}^{\bullet} \rightarrow \text { Cykliczny eter }+{ }^{\bullet} \mathrm{OH}
\end{gathered}
$$

Rodnik alkilonadtlenkowodoronadtlenku ulega wewnętrznej izomeryzacji z przeniesieniem wodoru i rozkładowi do ketowodoronadtlenku (ketohydroperoxide) i rodnika hydroksylowego według reakcji (11) i (12).

$$
\begin{gathered}
\mathrm{OOQ}^{\prime} \mathrm{OOH}^{\bullet} \leftarrow \mathrm{HOOQ}^{\prime} \mathrm{OOH} \\
\mathrm{HOOQ} \mathrm{OOH} \rightarrow \mathrm{O}=\mathrm{Q}^{\prime \prime} \mathrm{OOH}+\mathrm{OH}^{\bullet}
\end{gathered}
$$

Ketowodoronadtlenek tworzy dwa rodniki: rodnik karbonylowy i rodnik hydroksylowy według reakcji (13).

$$
\mathrm{O}=\mathrm{Q}^{\prime} \mathrm{OOH} \rightarrow \mathrm{O}=\mathrm{Q}^{\prime} \mathrm{O}^{\bullet}+\mathrm{OH}^{\bullet}
$$


Karbonylowy rodnik ulega rozkładowi do aldehydu najczęściej formaldehydu i rodnika ketylowego według reakcji (14).

$$
\mathrm{O}=\mathrm{Q}^{\prime} \mathrm{O}^{\circ} \rightarrow \mathrm{HCHO}+\left[{ }_{\mathbf{R}_{1}^{\prime}} \stackrel{\mathrm{II}}{\mathrm{C}_{\mathbf{R}_{\mathbf{2}}}}\right]^{\circ}
$$

Okres opóźnienia błękitnych płomieni trwa krótko, a uwolniona $\mathrm{w}$ trakcie wyżej wymienionych reakcji energia prowadzi do pojawienia się gorących płomieni i spalania wybuchowego węglowodorów, któremu towarzyszy gwałtowny wzrost temperatury, ciśnienia i emisji światła widzialnego $[4,5,7,8,10,23,29,36,41,43,44]$.

Według Ghosha [13] przebieg reakcji przedzapłonowych w obszarze zimnego i błękitnego płomienia modyfikują alkiloazotany stosowane jako dodatki zwiększające liczbę cetanową. Mechanizm przebiegu reakcji chemicznych zmniejszających opóźnienie zapłonu ( $\left.\tau_{\text {Chem }}\right)$ oleju napędowego przy użyciu alkiloazotanu przedstawiono na rysunku 6.

Znany i stosowany jako dodatek modyfikujący opóźnienie chemiczne zapłonu oleju napędowego azotan 2-ety-

$$
\begin{aligned}
& \mathrm{RO}-\mathrm{NO}_{2} \rightarrow \mathrm{RO}^{\bullet}+\mathrm{NO}_{2}^{\bullet} \\
& \mathrm{NO}_{2}^{\bullet}+\mathrm{RH} \rightarrow \mathrm{HONO}+\mathrm{R}^{\bullet} \\
& \mathrm{HONO} \rightarrow \mathrm{NO}+^{\bullet} \mathrm{OH} \\
& { }^{\circ} \mathrm{OH}+\mathrm{RH} \rightarrow \mathrm{H}_{2} \mathrm{O}+\mathrm{R}^{\bullet} \\
& \mathrm{R}^{\bullet}+\mathrm{O}_{2} \rightarrow \mathrm{RO}_{2}^{\bullet} \ldots \\
& 2 \mathrm{NO}^{\bullet}+\mathrm{O}_{2} \rightarrow \underset{2}{2 \mathrm{NO}_{2}^{\bullet}}
\end{aligned}
$$

Rys. 6. Mechanizm przebiegu reakcji chemicznych zmniejszający opóźnienie zapłonu $\left(\tau_{\text {Chem }}\right)$ oleju napędowego przy użyciu alkiloazotanu [13]

loheksylu (2-EHN), ulegając rozkładowi w zakresie temperatury od $198^{\circ} \mathrm{C}$ do $244^{\circ} \mathrm{C}$, tworzy wysoko reaktywny formaldehyd, który w interakcji z $\mathrm{NO}_{2}{ }^{\bullet}$ daje początek rozwojowi szybkich egzotermicznych rozgałęzionych reakcji łańcuchowych, według schematu przedstawionego na rysunku 7 [37].<smiles>CCCCC(CC)ON=O</smiles><smiles>CCCCC(CC)[O+][O-]</smiles><smiles>CCCCC(CC)C[O-]</smiles>

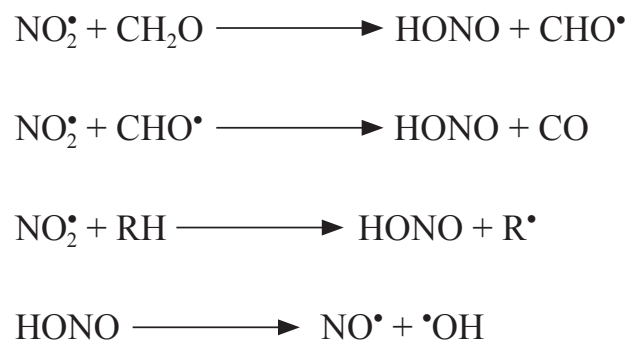

Rys. 7. Rozkład azotanu 2-etyloheksylowego (2-EHN) do formaldehydu i zapoczątkowanie rozgałęzionej reakcji łańcuchowej [33]

\section{Wpływ dodatku zwiększającego liczbę cetanową na proces spalania oleju napędowego}

Czas od chwili wtrysku paliwa do rozpoczęcia spalania (opóźnienie zapłonu) zależy od opóźnienia fizycznego i chemicznego zapłonu.

Na rysunku 8 zamieszczono przebieg procesu spalania wtryśniętej strugi oleju napędowego w silniku o zapłonie samoczynnym z bezpośrednim wtryskiem, z zaznaczeniem faz procesu spalania w funkcji kąta obrotu wału korbowego, odpowiedzialnych za kontrolę emisji $\mathrm{NO}_{\mathrm{x}}$ i PM [3, 25].

Proces spalania strugi paliwa w silniku z zapłonem samoczynnym można podzielić na cztery fazy [2]:
- faza pierwsza - okres opóźnienia samozapłonu (zwłoka samozapłonu) wynoszący około 1 milisekundy; w jej skład wchodzą zwłoka fizyczna i zwłoka chemiczna. Zwłoka fizyczna obejmuje odparowanie kropelek wtryśniętego paliwa i zmieszanie jego par z powietrzem oraz wytworzenie ośrodków samozapłonu. Zwłoka chemiczna, czyli czas chemicznego opóźnienia zapło$\mathrm{nu}$, to przedpłomienne reakcje utleniające, obejmujące procesy zimnopłomienne, błękitnopłomienne oraz gorącopłomienne; 


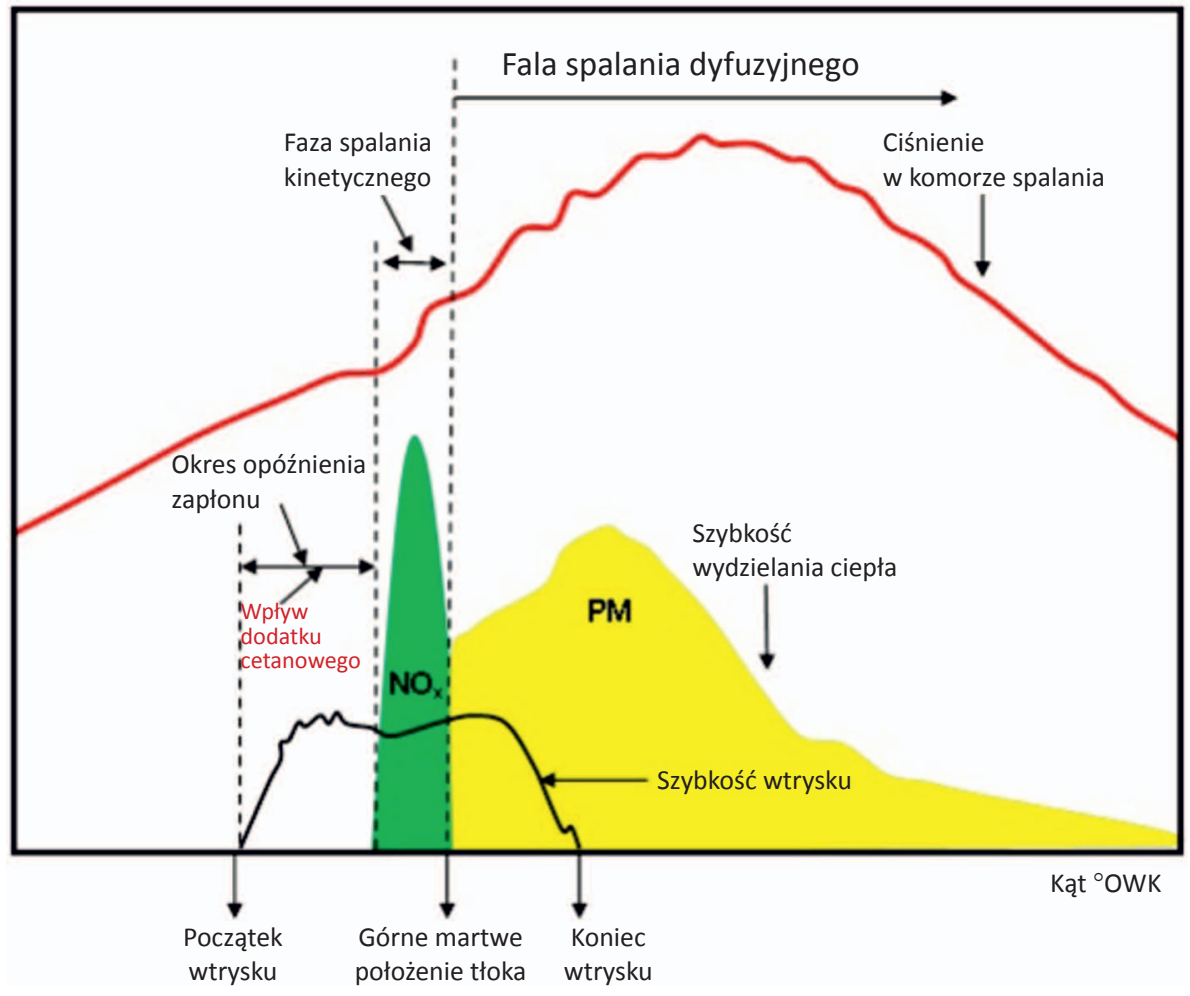

Rys. 8. Przebieg procesu spalania wtryśniętej strugi oleju napędowego w silniku o zapłonie samoczynnym z zaznaczeniem faz spalania odpowiedzialnych za kontrolę emisji $\mathrm{NO}_{\mathrm{x}}$ i PM [3, 25]

- faza druga - następuje po okresie opóźnienia samozapłonu jako spalanie niekontrolowane (kinetyczne). W okresie tym spalaniu ulegają pary otaczające strugę paliwa. Ciśnienie gwałtownie rośnie do $0,8 \mathrm{MPa} /{ }^{\circ} \mathrm{OWK}$;

- faza trzecia - okres spalania kontrolowanego (dyfuzyjnego). W tym okresie ciśnienie w komorze spalania osiąga maksymalną wartość do $8 \mathrm{MPa}$;

- faza czwarta - okres dopalenia paliwa, podczas którego niespalone resztki ulegają przemianom chemicznym pod wpływem gorących spalin. Dopalenie jest procesem niekorzystnie zmniejszającym sprawność cieplną silnika i zużycie paliwa.

Proces spalania kinetycznego oleju napędowego wtryśniętego do komory spalania w czasie okresu opóźnienia zapłonu związany jest z brakiem czasu na wymieszanie paliwa z powietrzem. Konsekwencją tego jest powstawanie lokalnych stref $z$ dużą wartością współczynnika nadmiaru powietrza, co sprzyja niskiej emisji cząstek stałych, tlenku węgla i niespalonych węglowodorów. Jednocześnie zapłon mieszaniny paliwo-powietrze powoduje dynamiczny proces spalania z dużą prędkością, wzrost ciśnienia i temperatury w komorze spalania, lecz generuje też tworzenie tlenków azotu i emisję hałasu. Po okresie kinetycznego spalania następuje okres spalania dyfuzyjnego. Przebieg szybkości wywiązywania się ciepła w okresie spalania dyfuzyjnego zależy głównie od intensywności procesu tworzenia mieszaniny paliwowo-powietrznej, na który wpływ mają mikroewaporacja, procesy dyfuzyjne, turbulencja oraz właściwości paliwa [22].

Rysunek 9 przedstawia zaproponowany przez Kamimoto i Bae przebieg procesu spalania kinetycznego i dyfuzyjnego mieszanki paliwowo-powietrznej, niezależny od czasu, w postaci diagramu składu mieszanki paliwo-powietrze określonej współczynnikiem stechiometrii $\phi$ - temperatura adiabatyczna płomienia $-T[9,20]$.

Diagram $\phi-T$ przedstawia obszar tworzenia się cząstek stałych (PM), zaznaczony kolorem żółtym, oraz obszar powstawania tlenków azotu $\left(\mathrm{NO}_{\mathrm{x}}\right)$, zaznaczony kolorem zielonym. Obszar w kolorze popielatym na diagramie $\phi-T$ przedstawia przebieg procesu spalania w konwencjonalnym silniku o zapłonie samoczynnym, z wtryskiem bezpośrednim wyznaczonym przez Kitamurę. Kitamura przebadał wpływ składu paliwa na tworzenie się sadzy (cząstek stałych) i tlenków azotu, w zależności od składu mieszanki paliwo-powietrze $(\phi-T)$.

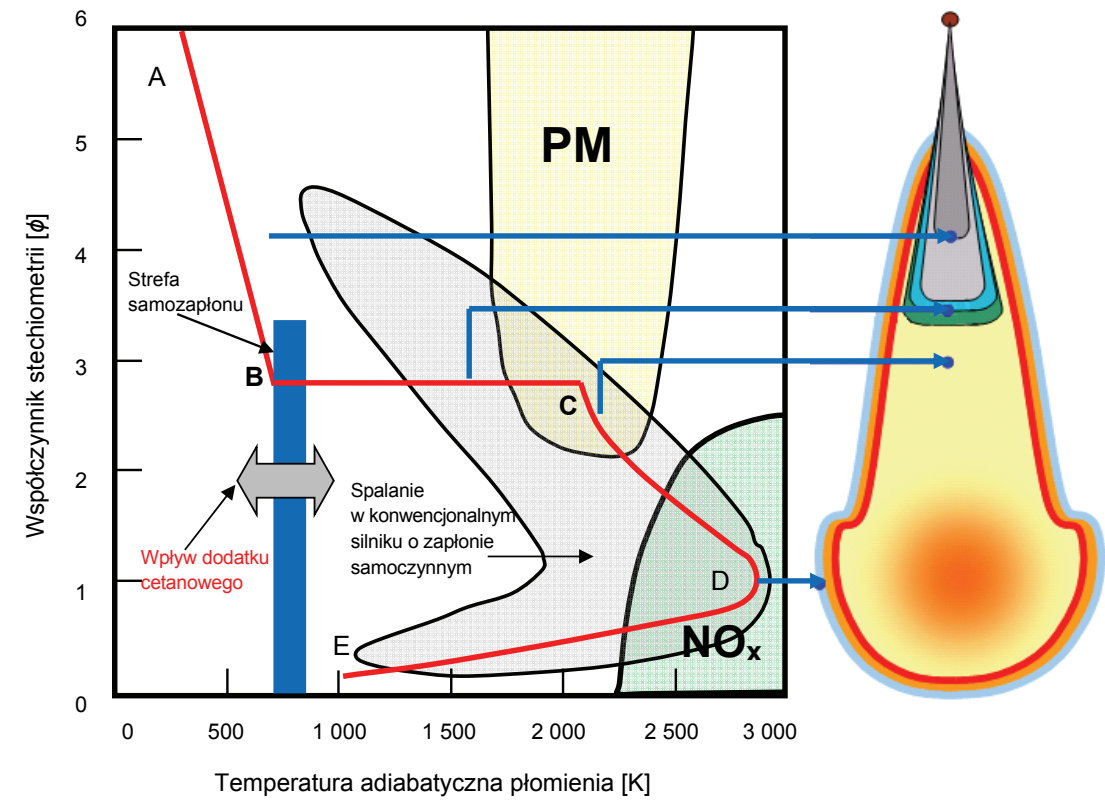

Rys. 9. Diagram $\phi-T$ przebiegu procesu spalania w silniku o zapłonie samoczynnym $[9,20]$ 
Emisję sadzy zaobserwował przy $\phi>2$ i temperaturze płomienia od $1600 \mathrm{~K}$ do $2500 \mathrm{~K}$, natomiast tworzenie tlenków azotu następowało w temperaturze wyższej niż $2200 \mathrm{~K}$, przy współczynniku stechiometrii $\phi<2$ [21].

Ciągła linia koloru czerwonego przedstawia typowy przebieg $(\phi-T)$ procesu spalania strugi paliwa w stanie quasiustalonym (we współrzędnych $\phi-T$ ), począwszy od wtrysku paliwa do fazy dopalania. Wtryśnięte paliwo do komory spalania miesza się z powietrzem do osiągnięcia temperatury samozapłonu (B). Odcinek B-C przedstawia fazę spalania kinetycznego, a odcinek $\mathrm{C}-\mathrm{D}$ fazę spalania dyfuzyjnego. Odcinek D-E oznacza fazę dopalania w obszarze $\phi<1$. Po prawej stronie diagramu $\phi-T$ przedstawiono model palącej się stru- gi paliwa w stanie quasi-ustalonym, opracowany przez Deca na podstawie pomiarów z użyciem techniki laserowej [11].

Kolorem ciemnoszarym zaznaczono strugę ciekłego paliwa, kolorem jasnoszarym - bogatą mieszankę paliwo-powietrze $(\phi=4)$, niebieskim - spalanie kinetyczne bogatej mieszanki, zielonym - początek tworzenia sadzy, żółtym - spalanie dyfuzyjne $\mathrm{w}$ wirze czołowym $\mathrm{w}$ fazie spalania dyfuzyjnego, natomiast kolorem czerwonym zaznaczono wysokotemperaturowy obszar tworzenia i aglomeracji cząstek sadzy. Czerwone obrzeże palącej strugi oznacza strefę utleniania cząstek sadzy, pomarańczowe określa fazę spalania dyfuzyjnego, jasnoniebieskie - strefę tworzenia termicznego $\mathrm{NO}_{\mathrm{x}}$

\section{Podsumowanie}

Zdolność oleju napędowego do zapłonu w silniku o zapłonie samoczynnym zależy od wielu istotnych czynników (charakterystyk), z których najważniejsze to mechaniczna charakterystyka silnika, charakterystyka paliwa, charakterystyka wtrysku i charakterystyka rozpylenia oleju napędowego.

Istotnym czynnikiem mającym wpływ na przebieg procesu spalania w silniku o zapłonie samoczynnym jest opóźnienie samozapłonu, a w szczególności czas opóźnienia chemicznego samozapłonu $\left(\tau_{\text {Chem }}\right)$. Czas opóźnienia chemicznego jest dużo krótszy od opóźnienia fizycznego samozapłonu (mikrosekundy) i rozpoczyna przebieg reakcji przedpłomieniowych, mających istotny wpływ na proces spalania w fazie spalania kinetycznego i dyfuzyjnego.

Przebieg wolnorodnikowych łańcuchowych reakcji przedpłomieniowych, mających istotny wpływ na czas opóźnienia chemicznego samozapłonu, modyfikują dodatki zwiększające liczbę cetanową typu alkiloazotanów, wpływające nie tylko na samozapłon oleju napędowego, lecz również na charakterystyke procesu spalania, powodując zmniejszenie zużycia paliwa oraz zmniejszenie emisji cząstek stałych, niespalonych węglowodorów, tlenku węgla i tlenków azotu.

Prosimy cytować jako: Nafta-Gaz 2017, nr 9, s. 651-659, DOI: 10.18668/NG.2017.09.04

Artykuł nadesłano do Redakcji 17.06.2017 r. Zatwierdzono do druku 26.07.2017 r.

Artykuł powstał na podstawie pracy własnej pt.: Ocena skuteczności działania dodatków do paliw, biopaliw i środków smarowych dla potrzeb produkcji doświadczalnej - praca INiG - PIB ze środków własnych; nr zlecenia: 1873/TM/16, nr archiwalny: DK-4100-/141/16.

\section{Literatura}

[1] Ambrozik A., Kruczyński S., Jakóbiec J., Orliński S.: Wpływ zasilania silnika spalinowego o zapłonie samoczynnym paliwem mineralnym i roślinnym na proces wtrysku oraz rozpad strugi paliwa. Journal of KONES Powertrain and Transport 2006, vol. 13, nr 3, s. 21-28.

[2] Arcoumanis C., Schindler K.P.: Mixture Formation and Combustion in the DI Diesel Engine. SAE Technical Paper 972681, 1997.

[3] Baumgarten C.: Mixture Formation in Internal Combustion Engines. Springer, Berlin, Heidelberg 2006.

[4] Blin-Simiand N., Jorand F. et al.: Hydroperoxides with zero, one, two or more carbonyl groups formed during the oxidation of n-dodecane. Combustion and Flame 2001, vol. 126, s. $1524-1532$.

[5] Blin-Simiand N., Jorand F. et al.: Ketohydroperoxides and ignition delay in internal combustion engines. Combustion and Flame 1998, vol. 112, s. 278-282.

[6] Cataluna R., da Silva R.: Effect of Cetane Number on Specific
Fuel Consumption and Particulate Matter and Unburned Hydrocarbon Emissions from Diesel Engines. Journal of Combustion 2012, article ID 738940, 6 s.

[7] Caton A., Hamilton J. et al.: Understanding ignition delay effects with pure component fuels in a single-cylinder diesel engine. Journal Engineering for Gas Turbines and Power 2011, vol. 133, nr 3.

[8] Chiang C., Myers P. et al.: Physical and Chemical Ignition Delay in an operating diesel engine using the hot-motored technique - part II. SAE Technical Paper 600057, 1960.

[9] Dec J.E.: Advanced compression - ignition engines - understanding the in-cylinder process. Proceedings of the Combustion Institute 2009, vol. 32, s. 2727-2742.

[10] Faravelli T., Gaffuri P. et al.: Detailed thermokinetic modelling of alkane autoignition as a tool for the optimization of performance of internal combustion engines. Fuel 1998, vol. 77, s. 147-155.

[11] Flynn P.F., Durrent R. et al.: Diesel Combustion: An Integrated 
View Combining Laser Diagnostics, Chemical Kinetics, and Empirical Validation. SAE Technical Paper 1999-01-0509, 1999.

[12] Gallant T., Franz J. et al.: Fuels for Advanced Combustion Engines Research Diesel Fuel: Analysis of Physical and Chemical Properties. SAE Technical Paper 2009-01-2769, 2009.

[13] Ghosh P.: Predicting the Effect of Cetane Improvers on Diesel Fuels. Energy and Fuels 2008, vol. 22, s. 1073-1079.

[14] Heywood J.B.: Internal combustion Engine Fundamentals. McGrill-Hill, New York 1988.

[15] Hiroyasu H., Arai M.: Structures of Fuel Sprays in Diesel Engines. SAE Technical Paper 900475, 1990.

[16] Idzior M., Karpiuk W. i in.: Analiza wplywu temperatury biopaliw na makro- i mikrostrukturę rozpylanych strug. Postępy Nauki i Techniki 2012, nr 15, s. 54-64.

[17] Idzior M., Lijewski P.: Możliwości określenia jakości rozpylenia paliwa przez wtryskiwacze silników ZS metoda badania parametrów strugi rozpylonego paliwa. Journal of KONES Internal Combustion Engines 2002, nr 3-4, s. 104-112.

[18] Jankowski A., Sandel A. et al.: Badania widma rozpylenia paliwa $w$ systemie Common Rail do silników z zapłonem samoczynnym. Journal of KONES Internal Combustion Engines 2002, nr 1-2, s. 311-322.

[19] Jankowski A., Sęczyk J., Zbierski K.: Badania strugi paliwa rozpylanej przez uklad wtryskowy common rail. Journal of KONES Internal Combustion Engines 2000, vol. 7, nr 1-2, s. 228-236.

[20] Kamimoto T., Bae M.H.: High combustion temperature for the reduction of particulate in Diesel engine. SAE Technical Paper 880423, 1988.

[21] Kitamura T., Itoetal T.: Mechanism of smokeless diesel combustion with oxygenated fuels based on the dependence of the equivalence ratio and temperature on soot particle formation. International Journal of Engine Research 2002, vol. 3, s. 223-248.

[22] Kuszewski H., Lejda K.: Wybrane metody ograniczenia toksyczności spalin silnika ZS w aspekcie limitów emisyjnych. Journal of KONES Powertrain and Transport 2006, vol. 13, nr 1, s. 279-287.

[23] Kuwahara K., Hiramura Y. et al.: Chemical Kinetics Study on Effect of Pressure and Fuel, $\mathrm{O}_{2}$ and $\mathrm{N}_{2}$ Molar Concentrations on Hydrocarbon Ignition Process. SAE Technical Paper 2012-01-1113, 2012.

[24] Ladommatos N., Parsi M. et al.: The effect of fuel cetane improver on diesel pollutant emissions. Fuel 1996, vol. 75, s. 8-14.

[25] Lakshminarayanan P.A., Aghaw Y.V.: Modeling Diesel Combustion. Springer Dordrecht, Heidelberg, London, New York 2010.

[26] Lotko W., Górski K.: Zasilanie silnika wysokoprężnego mieszaninami ON $i$ EETB. Wydawnictwa Naukowo-Techniczne, Warszawa 2011.

[27] Merker G.P., Schwarz Ch. et al.: Simulating Combustion, Simulation of combustion and pollutant formation for enginedevelopment. Springer-Verlag Berlin Heidelberg 2006.
[28] Nellson W.L.: Petroleum Rafinery Engineering. McGraw-Hill Company, New York 1968

[29] Ohta Y., Furutani M.: Identification of cool and blue flames in compression ignition. Polish Academy of Sciences, Archivum Combustionis 1991, vol. 11, nr 1-2, s. 43-52.

[30] Owen K., Coley T., Weaver C.S.: Automotive Fuels Reference Book. Society of Automotive Engineers 1990, $2^{\text {nd }}$ edition.

[31] Parkash S.: Petroleum Fuels Manufacturing Handbook. McGraw-Hill, New York 2010.

[32] Pipenger G.G.: Build a diesel fuel performance additive, the right way-Part 1. Hydrocarbon Processing 2016, vol. 95, nr 10, s. 71-74.

[33] Pritchard H.O.: Thermal decomposition of iso-octyl nitrate. Combustion and Flame 1989, vol. 75, nr 3-4, s. 415-416.

[34] Pszczółkowski J.: Tworzenie i spalanie mieszaniny paliwa i powietrza podczas rozruchu silnika o zapłonie samoczynnym. Journal of KONES Internal Combustion Engines 2002, nr 1-2, s. 225-232.

[35] Ra Y., McFarlane J. et al.: Effects of Fuel Physical Properties on Diesel Engine Combustion using Diesel and Bio-diesel Fuels. SAE Paper 2008-01-1379, 2008.

[36] Sahetchian K., Champoussin J.C., Brun M. et al.: Experimental study and modeling of dodecane ignition in a Diesel engine. Combustion and Flame 1995, vol. 103, s 207-220.

[37] Stanik W., Jakóbiec J., Wądrzyk M.: Czynniki konstrukcyjne kształtujace proces tworzenia mieszanki paliwowo-powietrznej $i$ spalania $w$ silniku o zapłonie samoczynnym. Combustion Engines 2013, vol. 154, nr 3, s. 40-50.

[38] Stone R.: Introduction to internal Combustion Engines. SAE International, Warrendale 1999.

[39] Taskiran O.O., Ergeneman M.: Experimental Study on Diesel Spray Characteristics and Autoignition Process. Journal of Combustion 2011, Article ID 5281126, $20 \mathrm{~s}$.

[40] Worldwide Fuel Charter. Fifth Edition, September 2013.

[41] Yu T., Uyehara O. et al.: Physical and Chemical Ignition Delay in an Operating Diesel Engine Using the Hot-Motored Technique. SAE Technical Paper 560061, 1956.

[42] Yuanwang D., Meilin Z. et al.: An analysis for effect of cetane number on exhaust emissions from engine with the neural network. Fuel 2002, vol. 81, s. 1963-1970.

[43] Zabłocki M.: Wtrysk i spalanie paliwa w silnikach wysokoprężnych. Wydawnictwa Komunikacji i Łączności, Warszawa 1976.

[44] Zedor J., Taatjes C.A. et al.: Kinetics of elementary reactions in low-temperature autoignition chemistry. Progress in Energy and Combustion Science 2011, vol. 37, nr 4, s. 371-421.

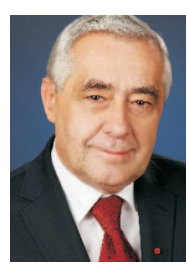

Dr Winicjusz STANIK

Główny specjalista badawczo-techniczny; Kierownik Zakładu Produkcji Doświadczalnej i Małotonażowej oraz Sprzedaży.

Instytut Nafty i Gazu - Państwowy Instytut Badawczy ul. Lubicz 25 A, 31-503 Kraków

E-mail: winicjusz.stanik@inig.pl 